\title{
Book Reviews/Boekbesprekings
}

\section{F.A. van Jaarsveld, A.P.J. van Rensburg en W.A. Stals (red.): Die Eerste Vryheidsoorlog 1880-1881. Pretoria, HAUM, 1980, 282 p., afbeeldinge, kaarte, R17,50.}

Dis merkwaardig dat hierdie boek presies honderd jaar na die betrokke oorlog gepubliseer word. Die publikasie daarvan is onderneem deur die Departement van Geskiedenis van die Universiteit van Pretoria.

Die inhoud word verdeel in vier dele:

I. Boereweerstand teen gedwonge Britse bestuur in Transvaal, 1877-1880 - Louis Scott.

II. Gewelddadige verset teen Britse oorheersing, 1880-1881 - J.E.H. Grobler en dr. C.M. Bakkes.

III. Skikking deur onderhandeling: Transvaal herwin sy onafhanklikheid, 1881-1884 - dr Maria Hugo en J.E.H. Grobler.

IV. Steun vir die onafhanklikheidstryd buite Transvaal: Afrikaner-nasionalisme - D.H. Heydenrych, S.F. Malan, M. Flemmer, F.A. van Jaarsveld en F.J. du Toit Spies.

Verder word dit aangevul deur 'n ryke bronnelys wat ook onderverdeel word as volg:

I. Literatuur.

II. Letterkundige Bronne.

III. Tydskrif - en Koerantartikels.

IV. Regeringspublikasies.

V. Historiese Manuskripte.

VI. Argivale Bronne.

Die outensiteit van hierdie bronne vertoon $\lg$ en weerspieël die uitdaging wat dit aan die redakteure en skrywers moes gebied het.

Die deeglikheid waarmee die materiaal gehanteer word, verdien die hoogste lof.

Die onderwerp is die botsing tussen Boer en Brit. Die bronne waaruit geput word verteenwoordig verskillende nasionaliteite, om te oordeel na die name bv. Appelgryn, Creswicke, Lehmann, Pitnut, Van Winter, Jorissen, Theal, ensomeer.

'n Onderwerp soos hierdie is emosiebelaai. Dis uiters moeilik om historiese feite objektief weer te gee met inagneming van die foute van die geledere enersyds in die goeie hoedanighede van die 'vyand' andersyds.
Een is verby. Die Amajubaposseëls wat onlangs verskyn het, beklemtoon die aktualiteit daarvan.

In hulle voorwoord verduidelik die redakteurs: Hoewel die Eerste Vryheidsoorlog wat skaars drie maande geduur het, herdenk word, spreek dit vanself dat dit nie ' $n$ geïsoleerde gebeurtenis van 1880-81 was nie; dit moet in samehang gesien word met die anneksasie van Transvaal in 1877 , en die het as motor gedien vir die versetbeweging wat tussen 1877 en 1880 vreedsaam en konstitusioneel verloop het.

Sowel binne- as buitelandse faktore het bygedra tot die beeïndiging van die Militêre stryd tussen Boer en Brit. Die Pretoriase en Londense Konvensies het die status van Transvaal ná die anneksasie en oorlog anders gereël, as wat dit vanaf die Sandrivierse Konvensie, van 1852 tot 1877 was.

Die stryd om die susereine onafhanklikheid van 1881, toegestaan met die Pretoriase Konvensie, deur voorwaardelike onafhanklikheid te vervang, is eers in 1884 besleg, waarby die 'Transvaalstaat' van 1881 weer tot die 'Zuid-Afrikaansche Republiek', omskep is, egter met 'n beperking op sy buitelandse beleid. Die jaar 1884 het die stryd wat in 1877 begin het, afgerond. Vandaar dat die boek die tydperk 1877 tot 1884 dek, met die oorlog in die sentrum geplaas.

Afgesien van 'n paar tydgenootlike werke oor die Eerste Vryheidsoorlog van Transvaal, van sowel Afrikaner - as Engelse kant, is daar aan dié tema nie veel aandag in die Suid-Afrikaanse geskiedskrywing gegee nie. Die rede lê voor die hand.

Hoewel Majuba vir die Transvaalse Boere van die grootste belang was, was hulle tot 1899 'n onderontwikkelde volk sonder 'n universiteit en sonder geleerdes of historici wat die gebeure tussen 1877 en 1884 kon navors.

Die Tweede Vryheidsoorlog van 1899-1902 was van so 'n omvangryke en traumatiese aard dat dit die Eerste 'Vryheidsoorlog (spoedig na die Tweede Vryheidsoorlog so genoem) in die skadu gestel het. En toe in die loop van die twintigste eeu wel historici opgelei is, het hul navorsing gewentel om die belangrikste oorlog van die twee wat sulke verreikende gevolge vir SuidAfrika en soveel lyding, ellende en herinnering 
gebring het. Die Eerste Vryheidsoorlog het as 't ware in die skadu van die Tweede skuilgegaan.

Benewens die sistematiese indeling van die materiaal is die afbakening metodies, en die skryftrant deurgaans boeiend.

Hierdie boek verdien 'n wye leserkring - nie net onder Geskiedenis studente nie, maar ook by die algemene leser wat in Geskiedenis belangstel.

Dit sou nuttelose haarklowery afgee om net kritiek onthalwe tekortkominge in hierdie puik werk te probeer naspoor. Van binne en buite is dit mooi. Dis stewig gebind en liggrys hardeband met bypassende kleure van swart, rooi en wit, wat naas die Pretoriase universiteitswapen die afbeelding van kmdt-genl Piet Joubert op die voorblad omsoom.

\section{A.D. Naudé}

\section{David Lloyd Owen: Providence Their Guide. London, Harrap, 1980, 238 p., illustrations and maps, foreword, preface, select bibliography index, R20,70.}

In his preface to this book the author quotes from Milton's Paradise lost, from which the title of this book is derived: 'Som natural tears they drop'd, but wip'd them soon; The World was all before them, where to choose Thir place of rest, and Providence thir guide; They hand in hand, with wandring steps and slow, Through Eden took thir solitarie way.

This is a personal account of the Longe Range Desert Group who operated between 1940 and 1945 during World War II.

It covers two areas and periods:

1. North Africa: June 1940-April 1943 and

2. The Dodecanese, Italy and the Balkans: May 1943-May 1945.

Useful hints are offered to the desert traveller: the most careful and detailed planning, firstclass equipment, a sound and simple communication system and a human element of rare quality.

On p.1 of Chapter 1 the author explains the motive of the LRDG: 'It was raised (and so remained throughout the five years of its existence) chiefly for the purpose of gathering information about the enemy behind his lines. It was never primarily intended to carry out offensive operations, which so often ruin the change of effecting successful reconnaissance.

Who can blame the hardened soldier for lyricism on the desert?:

In every age there have been explorers or tourists or perhaps, escapists or cranks who have fallen under the spell of the desert. They have succumbed to its lure and sometimes I find it difficult to explain just what is so magnetic about it ... Somehow one feels futtered by any of the harsh, resisting influences of human existence as we live in these days. There are no buildings, no roads, no street lights, no artificial or even natural noises, no hustle and bustle, no shout or to have money or to pretend about anything ... I personally think I know of nothing more restorative than lying on the soft sand - cool now after the retirement of the day's sun and just staring at the miracle of such a sky ... When the dawn comes, and the stars have all gone away, there is something sharp and exhilarating about the smell in the air. It is fresh and clean and tantalisingly different to the atmosphere which will pervade the day once the sun has come up over the distant horizon.'

The author admits: 'I have a feeling that it was a combination of those two influences - the awareness of danger and the awe-inspiring grandeur of the desert - that always marked the good relationship between those who served in the LRDG.'

He also offers a new approach to discipline: 'I had always disliked intensely the sort of discipline that relied on instant, unquestioning obedience and the fear of summary punishment. I had already discovered that you could get men to do anything you wanted if you let them know the reason, and if you showed them that you were going to do it with them.'

General Owen also learnt a lot about men: 'They had to be more than usually intelligent in order to understand fully the meaning of the task that the Patrol was given, and to contribute effectively towards achieving it. They had to have plenty of initiative to operate independently of supervision and control; they had to have acute powers of observation; they needed a speed of reaction which was faster than most; and I think they also had to have an unusual sense of responsibility 